\title{
The Many Faces of Dignity
}

\section{Review of Suzy Killmister, Contours of Dignity, Oxford University Press, 2020}

\section{Costanza Porro ${ }^{1}$ (1)}

Accepted: 2 September 2021 / Published online: 23 September 2021

(c) The Author(s) 2021

In Contours of Dignity, Suzy Killmister presents an innovative approach to the concept of dignity as well as a novel account of human dignity - the dignity that we possess simply qua humans. Firstly, and unlike many other theorists who aim at vindicating dignity, she does not propose a unified account of dignity as the correct or superior understanding of dignity. Instead, wishing to remain true to the different functions dignity has, Killmister presents three distinct strands of dignity. Her aim is not only to identify different conceptions of dignity, but also to argue for the usefulness of all of them for our moral thinking. In this connection, Killmister pays particular attention to the idea of human dignity. This is unsurprising given that centrality of the notion of human dignity in this literature. What is remarkable, however, is the account of human dignity that she defends. Killmister understands human dignity as an instance of status dignity, which we have in virtue of our membership in a particular category that commands respectful treatment from others. In the case of human dignity, the relevant category is that of the human. According to Killmister, this category is not to be understood as a natural kind but as a social category. In other words, we have dignity and we are entitled to respect because we have created a social category - the human - and attributed to it a rich meaning, which also involves the forms of respect typically understood as appropriate for human beings. Killmister's proposal breaks with the most prominent understanding of human dignity, the idea of Kantian origin that we have dignity in virtue of some capacity or property of ourselves, as well as the less influential albeit significant view that membership in the human species, understood as a natural kind rather than a social kind, grounds our dignity.

Killmister starts her book by laying out three desiderata for a theory of dignity. First, a theory of dignity must explain its connection to respect; second, it should capture the fact that some people have more or less dignity depending on their behaviour. Third, a theory of dignity should account for the fact that dignity is

Costanza Porro

costanza.porro@uni-hamburg.de

1 Institute of Philosophy, University of Hamburg, Hamburg, Germany 
fragile and can be not only violated but also damaged and in some extreme cases lost. The fragility of dignity plays a core role in Killmister's rejection of the dominant account of dignity, the conception of dignity as inner worth, which she presents in chapter 1 . Killmister argues that the dominant conception of dignity of Kantian origin, which understands it as a kind of special value grounded in some intrinsic features or capacities, typically autonomous agency, is unable to make sense of the ways in which dignity can be damaged or lost. If individuals have dignity due to their intrinsic properties, no action of others can harm it. The second reason to opt for a different conception of dignity is one that has been pointed out by many before, namely the idea that the dominant conception is exclusionary (McMahan 2007). If dignity is grounded in the possession of the capacity to act autonomously some human beings such as young children or those living with severe cognitive disability do not possess dignity.

Despite rejecting the dominant conception of dignity, Killmister does not opt, like other theorists have done (Sangiovanni 2017), to abandon dignity altogether because she believes that dignity has a wide array of significant roles to play in our moral lives. For this reason, she argues that instead of having one conception of dignity, to do justice to the richness and diversity of our uses of dignity, we should distinguish between three different strands of dignity. The first, personal dignity, is a form of dignity that we have if we take ourselves to be subject to particular kinds of norms that we wish to uphold. The second, social dignity, refers to cases when one is subject to dignitarian norms in virtue of their membership in a particular community or group. Thirdly, status dignity arises from membership in a particular category that commands respectful treatment for others. While in many cases they would co-exist, the distinction between personal and social dignity is straightforward as the former arises from cases when the agent takes themselves to be subject to particular norms, while status dignity refers to cases when others regard particular norms as applying to the person.

The distinction between personal and social dignity, on the one hand, and status dignity, on the other hand, is based on Killmister's ingenious take on the relationships between dignity and respect. The problem faced by Killmister, like other theorists of dignity before her, is that of how to reconcile the scalar side of dignity, which is connected to notions of dignified behaviour and elevated status, and the non-scalar side, which refers to a possession that humans all have and does not admit degree. Killmister addresses this challenge by postulating different kinds of dignity that correspond to different kinds of respect. Drawing on Darwall's famous distinction between two kinds of respect (Darwall 1977), Killmister argue that personal and social dignity call for appraisal respect, a form of positive or negative assessment of how dignified one is. These kinds of dignity need to be earned and admit degree depending on how well one upholds the dignitarian norms in question. Instead, status dignity invites recognition respect, which does not come in degree and amounts to the acknowledgment of a feature of a person and the corresponding way in which she is to be treated. In the case of human dignity, which is a kind of status dignity, this amounts to recognising that one is a human and in virtue of this she is owed the kind of respectful treatment owed to human beings. 
Equipped with these useful distinctions, the following chapter is dedicated to the analysis of the fragility of dignity. Rather than only pointing to the vulnerable character of dignity, Killmister offers a nuanced and detailed analysis of the various ways in which the different kinds of dignity can be violated, harmed and even lost. The third chapter mirrors the second one in that it offers an account of the conditions under which we have a claim to personal and social dignity. Killmister cleverly analyses the interconnections between shame, self-respect, integrity, agency and dignity attacks. Moreover, she addresses the thorny problem of how to conceive of cases in which personal dignity or social dignity are based on norms that we find objectionable, such as sexist or homophobic norms, and whether in such cases people have a claim against dignity violation, e.g., for a man a norm against being treated like a woman.

The last two chapters of the book are dedicated more specifically to human dignity. Killmister sets the scene with a discussion of the grounds and the conditions under which we have a claim to status dignity. Killmister focuses on human (social) kinds, categories of people that exist in virtue of social conventions, such as royalty, citizens and, of course, humans. The obvious question that arises is why we should derive normative implications from these social kinds. This question appears even more pressing if we consider that much of the literature on social conventions has the opposite aim, namely debunking the norms and expectations attached to these social kinds. Killmister argues that denying people membership in a category and the respect due to its members is an affront to their identity which harms their selfunderstanding as well as their social position. Not in all cases, however, does the claim not to have one's social dignity violated succeed. A core set of cases where this claim does not succeed, in Killmister's view, are those in which the human kind in question is oppressive, such as in the case of white or man. In many social contexts being accorded the respect owed to white people or men perpetuates the oppression of those who do not belong to the group; as a consequence, the claims against these dignity violations do not succeed. Moreover, for one to have a claim against status dignity violations one should be a member of the group in question. This latter condition gives rise to questions on how to determine who a member is. Killmister argues that it is not possible to provide a unitary answer to the question of membership for all human kinds and this issue should be evaluated case by case.

Drawing on this, the last chapter discussed human dignity and its connection to human rights. The core idea is that our human dignity is grounded in the social category human, which is conceptually distinct from the natural kind human. In Killmister's view, while there is of course no universal consensus about the meaning and the norms associated with the human and there are differing versions of the human, there is also a global variant of the human which has global reach and can be used as the referent for this category. This global variant has taken shape and is deployed in the context of human rights culture. Human dignity so understood encompasses both the formal rights recognised by treaties and international law and more informal norms of respect, which result from our social practices. For Killmister, the relationship between human dignity and human rights is therefore different from the one imagined by the proponents of the orthodox approach, according to which human beings have dignity in virtue of some inner capacities, and dignity, in 
turn, grounds human rights. In Killmister's view, there is a looping effect between these two notions. The category of the human and the idea of human dignity have emerged out of the human rights culture; however, the idea of us as having dignity and being human rights holders, once in place, itself shapes our understanding and our claiming of rights, becoming a foundations, a standpoint from which existing human rights norms and practices can be assessed and criticised.

Contours of Dignity is a very rich book which offers a genuinely innovative approach to the idea of dignity. In my view, one of the main merits of the book is its ability to capture the different roles that dignity can have in our moral thinking and especially the tension between the scalar and the non-scalar strands of dignity. In chapter 2, Killmister persuasively shows that the ubiquity of dignity-based claims in response to a variety of different harms and wrongs arises from the fact that when we talk of dignity we have in mind an array of different ideas. For instance, an act is a violation of our personal dignity when it forces us to do something that goes against our own norms, while it violates our social dignity if it involves forcing us to do something socially debasing-regardless of what we might think of it or even if we are able to conceptualise this violation as such. Finally, a violation of status dignity does not involve making us less dignified-either personally or sociallybecause of our behaviour, but instead involves a failure to treat us with the appropriate respect.

Nonetheless, one could also regard the focus on different strands of dignity as one of the limits of the book, for one of two reasons. Firstly, one might aim for a higher degree of unity when thinking about contested concepts such as dignity. As the trade-off is between unity and the explanatory power of the account, Killmister provides us with good reasons to side with her in this dispute. Secondly, and in my view more importantly, those who regard the idea of human dignity as the one of central interest when reflecting on dignity are likely be left unsatisfied with the relatively limited amount of space that Killmister dedicates to human dignity, which leaves some important questions about the category human, its content and its origin unanswered.

Further, some of the conclusions on human dignity reached by Killmister seem to me problematic. One such example is the problem of whether and on which grounds violations of human dignity represent a particularly objectionable instance of wrongdoing, which is a view that many writing on dignity hold. While Killmister acknowledges the existence of a specific harm arising from a failure to be treated as a human being, this harm and the corresponding claim to human dignity arises from our interests in self-understanding and social standing, which are the same interests that trigger all claims to be recognised as a member of a social kind. Therefore, while harms to human dignity might be distinct from other harms there are no reasons to believe they are uniquely or distinctively wrong, insofar as they do not have unique wrong-making features. Further, Killmister addresses the question of whether the human might in fact be an oppressive kind and, therefore, like in the case of man or white discussed above, constitute an inappropriate ground for a claim against dignity violations. While she concludes that is probably not the case, she herself admits her conclusion to be tentative. In her view, the human has the potential to support valid claims but does not straightforwardly do so. This further 
underscores the impression that her theory is unable to afford the special place that many have accorded to human dignity and its violations.

Another aspect of Killmister's account of human dignity that I find concerning has to do with the conditions of membership in the category of the human. The core question is on which grounds those who are not regarded as members of the relevant category can claim their dignity and oppose dignity violations of which they are victim. Killmister addresses this issue by discussing the example of Jim Crow America, in which the status dignity of African Americans as citizens was systematically violated by segregation. She argues that, despite the fact that African Americans were not accorded the appropriate respect due to citizens, suggesting they were not part of the human kind citizen, her proposal can account for this case. This is because, following Searle, she argues that in some cases, such as citizenship, membership in a human kind is decided by formal rules and, in this case, since the ratification of the 14th Amendment, African Americans were in fact formally recognised as citizens and therefore entitled to the recognition respect due to citizens. This reply brings out two problems. On the one hand, one might wonder what happens in cases where formal conditions for membership are in place but particular groups fail to meet these conditions, such as in the case of African Americans prior to the ratification of the $14^{\text {th }}$ Amendment. The fact that they were not formally citizens then seems to imply that they did not possess the status dignity of a citizen and were therefore not entitled to respect. Importantly, this applies to any group which historically or at present is stripped of its citizenship, which is problematic for Killmister's account. On the other hand, the question of membership arises for categories, such as the human, which do not have formal conditions for membership. Killmister acknowledges that membership in the category human is far less fixed. She compares a Searlean approach to the issue of membership in the human kind to the conferralist and context-sensitive approach defended by Ásta and argues that on both accounts what it takes to be a member of the human kind is that the global community recognises you as a member. This condition, she argues, is currently satisfied by all human beings thanks to the existence of the global variant of the human. For her, it is actually an advantage of a social constructivist approach to the human that it can allow for its scope and meaning, including the content of human rights, to change. However, this exposes the category to not only potential broadening and progressive changes but also shrinking, in case the global norm of the human were to change to exclude some human beings. Further, if we follow Killmister's analysis of the human, given that the global variant of the human takes shape only during the last century, we should conclude that (human) dignity violations prior to that do not count as such. Also in this area, a social constructivist position on the human is inherently unable to offer the bedrock principle that many wish to arrive at when thinking about human dignity.

In conclusion, Killmister's book offers a nuanced and innovative account of dignity which has the merit of explaining the different and often seemingly contradictory roles that dignity plays in our moral lives. However, the question remains whether it is indeed possible to do justice to the internal diversity of dignity and abandon the dominant account of human dignity in favour of a social constructivist position, without abandoning the idea, so central in much of our moral, political and 
legal thinking, that human dignity has a uniquely important place in our normative landscape.

Funding Open Access funding enabled and organized by Projekt DEAL.

Open Access This article is licensed under a Creative Commons Attribution 4.0 International License, which permits use, sharing, adaptation, distribution and reproduction in any medium or format, as long as you give appropriate credit to the original author(s) and the source, provide a link to the Creative Commons licence, and indicate if changes were made. The images or other third party material in this article are included in the article's Creative Commons licence, unless indicated otherwise in a credit line to the material. If material is not included in the article's Creative Commons licence and your intended use is not permitted by statutory regulation or exceeds the permitted use, you will need to obtain permission directly from the copyright holder. To view a copy of this licence, visit http://creativecommons.org/licen ses/by/4.0/.

\section{References}

Darwall, Stephen L. 1977. Two kinds of respect. Ethics 88 (1): 36-49.

McMahan, Jeff. 2007. Challenges to human equality. The Journal of Ethics 12 (1): 81-104.

Sangiovanni, Andrea. 2017. Humanity without dignity: Moral equality, respect, and human rights. Cambridge, MA: Harvard University Press.

Publisher's Note Springer Nature remains neutral with regard to jurisdictional claims in published maps and institutional affiliations. 